\title{
Study of Karpoor Ghrita and Povidine Iodine in Sadyo Vrana
}

\author{
Research article
}

\section{Sandeep T Nikam ${ }^{*}$}

1. Registrar, Shalya-Shalayakya Department, Aryangla Vaidyak Mahavidyalaya, 6 Shukravarpet, Satara.

\begin{abstract}
Aims: Study of local use of Karpoor ghrita and Povidone- Iodine in Sadyovrana. Objectives: 1.To study comparative effect of karpoor ghrita and Povidone- Iodine in sadyovrana. 2. To study assess the effect of 'karpoor ghrita' in minimizing infections after injury. 3. To study compare the days for wound healing for both drugs. As the reference has been quoted from Sadyo Vrana Chikitsadhyaya, the formulation of this medicine is to be used only in Sadyo Vranas i.e. Shuddha Vrana. Methods: In this study 60 Diagnosed Patients Of sadyovrana were Taken From O.P.D And I.P.D Of Shalyatantra Department Of hospital. Clinical was Conducted.Computer Generated Random Number Table Were Used For Clinical Trial. Trial group 30 Patients Of karpoor ghrita dressing and control group 30 patients of povidone- iodine dressing were Enrolled Under Following Groups Irrespective Of Sex And Religion. Observations and results: In this clinical study it is seen that, Clinical parameters like Vedana, Varna, Akruti, Gandha, were significantly reduced after treatment in Trial group than in Control Group and srava showed equal results. Number of Days required for ropan were less in Trial group than that in Control Group. After testing the effectiveness of Karpoorghrita treatment against the Standard betadine Treatment, results showed that The Karpoorghrita treatment has better results than the Standard betadine in Sadyovrana Patients.
\end{abstract}

Key words: Sadyo vrana, Wound healing, Karpoor, Shatdhauta ghrita, Malhar kalpana, Karpoor ghrita

\section{Introduction}

SADYO VRANAs mostly occur due to accidental injuries. As we see in today's world the number of major \& minor injuries taking place has increased.(1)

Sushruta Samhita has given superior position to Vrana. Sutrasthan of this samhita shows description of the Vrana in most of the chapters and Chikitsa Sthana begins with Chapter for Vrana(2). Shalyatantra brings out very clearly that vrana is the most significant surgical entity, its knowledge and effective management for a surgeon is the basic skill required.

Surgery and wound go hand in hand, the wound may be due to some kind of trauma or be it by the surgeon's knife. In todays fast paced life safety is taking a back seat leading to many kind of injuries especially common are abrasions and lacerations mostly seen in road traffic accidents. Sadyovrana is an entity we commonly come across, it is associated with a lot of pain and caused due to external trauma.

The mechanism of wound healing depends on certain factors which have centred mainly on prevention of vitamins, trace element and protein deficiencies that delay wound healing. There are some chemical agents that promote wound healing, but they

\footnotetext{
*Corresponding Author:

Sandeep T Nikam

Registrar, Shalya-Shalayakya Department, Aryangla

Vaidyak Mahavidyalaya, 6 Shukravarpet, Satara

Mobile No: +91-9850487568

E-mail: drsandeepnikam.ms@gmail.com
}

are scarce and requiring various desirable effects and needs of healing feature for betterment. Since time immemorial, its been an ongoing process to search better remedy to minimize and overcome drawbacks of previous ones.

The aim of treating a wound is to either shorten the time required for healing or to minimize the undesired consequences. There are many factors responsible to make healing process delayed like dead tissues, insufficient blood supply, protein deficiency, diseases like diabetes mellitus, tuberculosis etc(3). In case of delayed healing, it is more likely to be local than general which clarifies the magnitude of the problem of study. Many investigations and experiments have been carried out in medical science to understand the phenomenon of wound healing. Analgesics, antibiotics and antiseptics like Povidone iodine, Silver sulphadiazine etc are in use for the treatment of wounds.These treatment modalities still have their own limitations and side effects. Attention is directed to discover an agent which will accelerate wound healing with less side effects. Modern day treatment of wound does not comprise of a single drug offering both properties of cleaning and healing of wound by the same drug. That is why the search is still on to find out a drug which can fulfil the optimal requirement.

Ayurveda is an applied science and time tested health system with vast scope of trails to prove certain principles as well as therapeutic effects of medicines.

SADYO VRANA is in Shuddha state for 7 days so; if these Vranas are treated within 7 days their chances 
of getting infected are reduced.(4).Karpoorghrita mentioned in Sadyovrana chikitsa was chosen as according to its reference mentioned in Sadyovrana it possesses healing property vrana ropan(5). Povidone iodine is an excellent drug as far as cleansing is concerned but it to some extent interferes in healing of wound. To compare and understand there effects on wound Karpoorghrita and povidone iodine were chosen.

Studies reveal that it is difficult to achieve complete aim of wound management with single agent hence there is need to find out a single effective formulation which possesses vrana ropana property without wound infection.

There lies an extensive scope of research in ayurveda which would prove beneficial to the society. It would be cost effective and with less complications. Hence various formulations need to be revived, tested and used in treating wounds. An attempt to revive an important preparation is done here.

\section{Materials and Methods}

A] Conceptual study: Literary study of karpoorghrita and Vrana was done.

\section{B] Cllinical trial: \\ Selection of patient-}

For present clinical study 60 patients of sadyo Vrana were selected from O.P.D. and I.P.D. department of Shalyatantra of hospital. These patient were selected irrespective of their age, sex, religion, educational, marital, and socio economic status. Detailed history of all patient were obtained as per prepared proforma . Routine investigations were done like haemogram, urine routine, B.S.L.random, .Random sampling of patients was done. Informed written consentof each patient taken for the study. Then clinical trial was conducted.

Grouping of patient-In present clinical study, two groups were doneasfollows. In each group 30 patients of sadyo Vrana were selected for study. In each group wound cleaned with normal saline.

- Group A (Trial Group) - Vrana Karma done with Karpoorghrita.

- Group B (Control Group) -Vrana Karma done with Povidone-Iodine.

\section{Criteria for inclusion}

- Ghrishta Vrana(Abrasions)

- Kshataja Vrana(laceration)

- Due to trauma \&accident .

\section{Criteria for exclusion}

- Chhinna Vrana,

- Bhinna Vrana,

- Viddha Vrana,

- PichchitaVrana

\section{Withdrawal criteria-}

- Patient is not responding to the treatment and aggravation of symptoms within 7 days.

- Patient refuses to continue the treatment.
Drug Review

Ayurvedic Review

Karpoorghrita : (6)

\begin{tabular}{|l|l|l|l|}
\hline No. & $\begin{array}{l}\text { Ingredients/ } \\
\text { Botanical Name }\end{array}$ & Part used & Quantity \\
\hline 01. & $\begin{array}{l}\text { Karpoor } \\
\text { Cinnamomum } \\
\text { camphora (L.) J. } \\
\text { Presl. }\end{array}$ & Resin & $10 \mathrm{~g}$. \\
\hline 02. & shatdhauta ghrita & Ghee & $60 \mathrm{~g}$. \\
\hline
\end{tabular}

\section{Preparation of shatadhauta ghrita :(7)}

Washing goghrita again and again for a total of 100 times with water gives shatadhauta ghrita which possess the properties of allievating pitta, daha and is vrana ropana.

\section{Materials :}

- Copper vessels - pan, agitator

- Goghrita (cows ghee)

- Distilled water

Method :

- Copper vessels were cleaned properly and and thoroughly rinsed with water.

- Desired amount of goghrita was taken in a copper pan.

- Two times of ghrita amount of water was added to it.

- Mardan (agitation) of goghrita and water was done with the help of manual copper agitator (vessel) for 5 to 8 minutes.

- The contents were allowed to settle. The water was decanted carefully to avoid loss of ghrita.

- Again little amount of water was added to the previously washed goghrita and the same process of mardan was done.

- This process was done one hundred times to obtain shatadhauta ghrita.

- The obtained sample was used futher asa base to prepare Karpoorghrita.

\section{Properties of Shatadhauta ghrita :}

- Has better consistent and viscous than ghirta and hence useful in topical application.

- Reduction in particle size facilitates increased absorption through skin(8).

- Copper content makes it anti-inflammatory.

Preparation of drug karpoorghrita : It is prepared by Malhar kalpana (9).

Materials :

- Upadhan dravya (Base) : Shata dhauta ghrita $60 \mathrm{gm}$

- Adhan dravya (main ingredient) : karpoor -10gm

- A pan 
Method :

- The preparation was done according to tirturation (peshana) method for malhar kalpana.

- essel used was cleaned and rinsed thoroughly with water.

- 10 gm shatadhauta ghrita was taken and and equal quantity of fine standardized karpoor churna sieved an pharmacy was added to it.

- Shatadhuta ghrita was added in increasing order till a mixture free of grittiness was obtained.

- Tirturation (peshana) of the above mixture was carried out till a homogeneous mixture was obtained with good consistency.

- The sample of karpoorghrita malhar thus obtained was stored.

- The prepared malhar stored in the sterilized bottles and used for clinical trial on the patients. Standerdisation of final product done.

\section{Raspanchaka of dravyas used in Karpoorghrita(10):}

No. Ingredient Rasa/ Guna/ Virya/ Vipaka/

Dosha Karma

01. Karpoor Tikta, Katu, Madhur rasa, Laghu, Tikshna guna, Shita virya, Katu

vipaka and Tridoshahara

02. Shatdhaut Madhur rasa, Snigdha, Guru, ghrita Shita guna, Shita virya, Madhura vipaka, Tridoshahara

\section{Modern Review:}

Povidine-Iodine(11)

Generic name- Povidone - iodine

IUPAC name-

2-Pyrrolidinone, 1-ethenyl-, homopolymer, compd. with iodine.

\section{Chemical formula-}

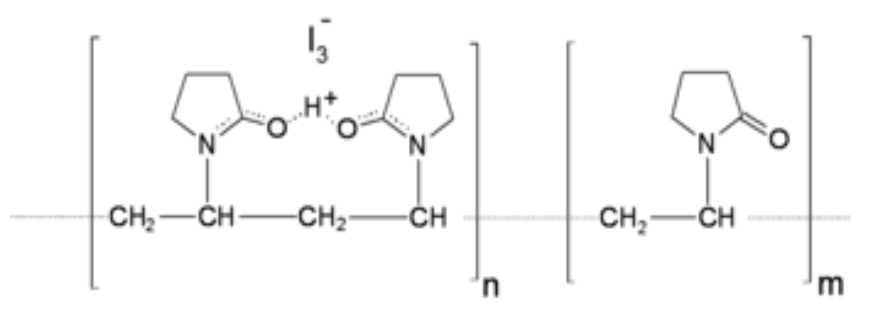

\section{Properties and effects}

Iodine is as an effective and useful germicide.

It is very effective against variety of microorganisms such as viruses, bacteria, protozoa, yeast and fungi.

However its frequent use is contraindicated because its insolubility and its staining and irritating properties. Many of these undesirable qualities of iodine could be eliminated by combining it with polyvinyl pyrrolidone (povidone). This organic polymer is water soluble, when it is combined with iodine.

A complex is formed in which iodine's toxic effects are lost without its bacterial activity being affected. This complex, povidone, iodine (Polyvinyl pyrroiodone iodine) abbreviated as pvp-1has been used effectively as a surface disinfectant. Povidone is an effective germicide. High dilutions are active in destroying organisms within 15 seconds. Color loss is accompanied by the weakening germicidal activity.

\section{Assessment Criteria}

Subjective parameters taken and the Grading pattern of the parameters is as follows

\section{Vedana:}

The vedana will be assessed by visual analogue scale. A $10 \mathrm{~cm}$ visual analouge scale of pain will be used for measurement.

\section{Akruti}

$\begin{array}{ll}\text { Grade I } & <5 \mathrm{~cm} \\ \text { Grade II } & 5-10 \mathrm{~cm} \\ \text { Grade III } & 10-20 \mathrm{cms}\end{array}$

\section{Varna}

No Granulation of tissue

Granulation of tissue

1

(Ruhyaman vrana )

Pale base of wound.

Yellowish slough at base \& edges. 3

\section{Gandha}

No smell

Foul smell

1

\section{Srava}

No discharge

Bloody discharge

Serous discharge

Purulent discharge

Heavy Purulent discharge

\section{Clinical End-points:}

Primary End-point: 7 days in which suddha avastha of sadyo vrana maintained and clinical symptoms reduced completely if wound care taken properly.

Secondary End-point: Total days for Ropan was considered as the secondary end-point for the study. 


\section{Observations and Results}

Efficacy testing of the treatment was performed using Two-way ANOVA for repeated measures.

Table 1 Showing the TWO-Way ANOVA Results for the various parameters taken :

\begin{tabular}{|l|l|l|l|l|l|l|}
\hline Measure & Correction & \multicolumn{1}{c|}{$\begin{array}{c}\text { Type III } \\
\text { Sum of Squares }\end{array}$} & \multicolumn{1}{c|}{ Df } & $\begin{array}{c}\text { Mean } \\
\text { Square }\end{array}$ & \multicolumn{1}{|c|}{ F } & P-value \\
\hline Vedana & $\begin{array}{l}\text { Greenhouse- } \\
\text { Geisser }\end{array}$ & 3538.85 & 2.68 & 1316.85 & 571.87 & 0.03 \\
\hline Srava & $\begin{array}{l}\text { Greenhouse- } \\
\text { Geisser }\end{array}$ & 29.28 & 2.12 & 13.80 & 24.78 & 0.049 \\
\hline Akruti & $\begin{array}{l}\text { Greenhouse- } \\
\text { Geisser }\end{array}$ & 6.13 & 1.87 & 3.27 & 10.42 & $<0.005$ \\
\hline Varna & $\begin{array}{l}\text { Greenhouse- } \\
\text { Geisser }\end{array}$ & 95.09 & 3.59 & 26.47 & 112.61 & $<0.005$ \\
\hline Gandha & $\begin{array}{l}\text { Greenhouse- } \\
\text { Geisser }\end{array}$ & 6.68 & 2.69 & 2.484 & 15.54 & $<0.005$ \\
\hline $\begin{array}{l}\text { Significance Threshold: } \\
\text { P }<0.05: \text { P-values less than } 0.05 \text { will be considered to be significant }\end{array}$ & & & \\
\hline
\end{tabular}

Based on these criteria, the percentage relief in both the groups was as follows:

\begin{tabular}{|l|l|l|}
\hline \% relieved & Trial & Control \\
\hline Vedana & 86.66 & 73.33 \\
\hline Srava & 80 & 80 \\
\hline Akruti & 86.66 & 80 \\
\hline Varna & 86.66 & 80 \\
\hline Gandha & 80 & 53.33 \\
\hline
\end{tabular}

Graph 1: Showing the percentage of relief in the parameters in both the groups as below:

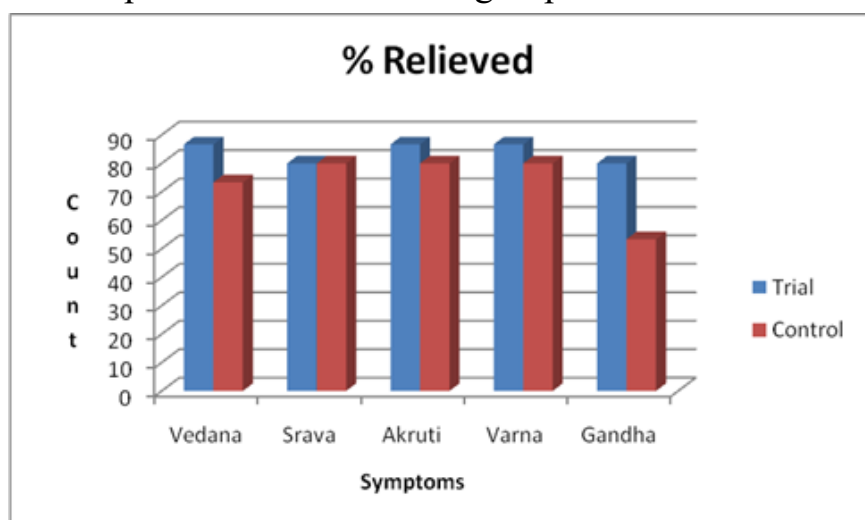

It is clear from the above graph that the $\%$ of relieved patients is higher in the Trial group for Vedana, Akruti, Varna, Gandha symptoms. For Srava, the \% relief for trial and control is same. Thus, it can be concluded that the trial group treatment is more effective than the control group treatment as far as relief is concerned.

\section{Days required for Ropan:}

The total number of days for ropan required for patients in Trial vs Control group shows us the efficacy of the treatment in trial group as below:

\begin{tabular}{|l|l|l|l|l|}
\hline & \multicolumn{2}{|l|}{ Trial group } & \multicolumn{2}{l|}{ Control group } \\
\hline $\begin{array}{l}\text { Total } \\
\text { days for } \\
\text { ropan }\end{array}$ & $\begin{array}{l}\text { Number } \\
\text { of } \\
\text { patients }\end{array}$ & $\begin{array}{l}\text { \% of } \\
\text { patient }\end{array}$ & $\begin{array}{l}\text { Number } \\
\text { of } \\
\text { patients }\end{array}$ & $\begin{array}{l}\text { \% of } \\
\text { patients }\end{array}$ \\
\hline $\mathbf{6}$ to 10 & 24 & 80 & 17 & 56.66 \\
\hline $\begin{array}{l}\mathbf{1 1} \text { to } \\
\mathbf{1 5}\end{array}$ & 6 & 20 & 13 & 43.33 \\
\hline $\begin{array}{l}\mathbf{1 6} \text { to } \\
\mathbf{2 0}\end{array}$ & 0 & 0 & 0 & 0 \\
\hline Total & 30 & 100 & 30 & 100 \\
\hline
\end{tabular}

Graph 2: Showing the Time taken for the ropana in both the groups as below:

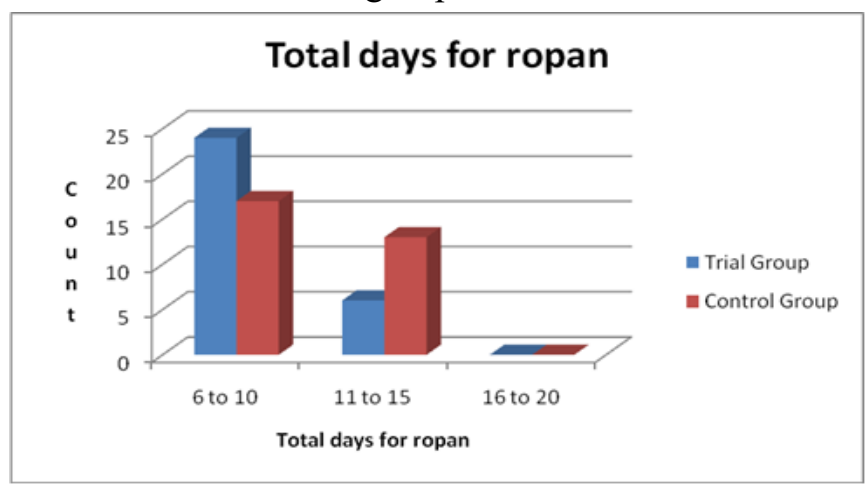

It can be concluded from the graph that $80 \%$ patients from the Trial group needed only upto 10 days for Ropan, while only $56.6 \%$ of the patients from control group fall under this class.Also, effectively, the $\%$ of patients from trial group that needed 11 to 15 days for Ropan are subsequently lesser than their counterparts in the control group. 


\section{Discussion}

It is clear from above that $\%$ of relieved patients is higher in the trial group for each symptom. Thus it can be concluded that the trial treatment is more effective than the Control Group as far as relief is concerned.

\section{Vedana :}

After treating the patients from trial group with karpoor ghrita, assessment of Vedana shows pvalue $=0.03$. Thus we accept alternate hypothesis. So it can be said that Vedana after treatment with karpoorghrita was significantly reduced than Vedana when treated with betadine treatment.

Vedana may be reduced due to soothing effect of shatadhuta ghrita.

\section{Srava :}

After treating the patients from trial group with Karpoorghrita, assessment of Srava shows pvalue $=0.049$. Thus we accept null hyopthesis. So it can be said that Sravawith both karpoorghrita and betadine showed equal results aftertreatment.Sravamay have controlled due to Raktasthambhak, sheetaveerya, $s$ irasankochak properties of content of the preparation.

\section{Varna:}

After treating the patients from trial group withKarpoorghrita, assessment of Varna shows pvalue $=<0.05$. Thus we accept alternate hypothesis. : Karpoorghritatreatmentin patients of sadyovrana results in better granulation of varnathan the Betadine treatmentover the period of treatment.

\section{Akruti:}

After treating the patients from trial group withKarpoorghrita, assessment of Akruti shows pvalue $=<0.05$. Thus we accept alternate hypothesis. So it can be said that Akruti after treatment with karpoorghrita was significantly reduced than Akruti with betadine treatment.

Akruti was controlled due to ropana andSandhan property of drug and helped wound contraction.

\section{Gandha :}

After treating the patients from trial group with Karpoorghrita, assessment of Gandha shows pvalue $=<0.05$. Thus we accept alternate hypothesis thatKarpoorghritatreatmentin patients of sadyovrana results in less gandhaat the end of treatment than betadine.

\section{Days Required for ropan:}

From the statistical analysis it can be concluded that $80 \%$ patients from Trial group needed only upto 6 10 days of ropan, while only $56.66 \%$ of patients from control group fall under this class. Also $20 \%$ of patients from trial group that needed 11 to 15 days of ropan as opposed to $43.33 \%$ patients from control group and which is significantly more.

\section{Total Effect of Therapy}

In this clinical study it is seen that, Clinical parameters like Vedana, Varna, Akruti, Gandha, were significantly reduced after treatment in Trial group than in Control Group and srava showed equal results.

Number of Days required for ropan were less in Trial group than that in Control Group.

\section{Comparitive Study :}

After testing the effectiveness of Karpoorghrita treatment against the Standard betadine Treatment, results showed that The Karpoorghrita treatment has better results than the Standard betadine in Sadyovrana Patients.

\section{Probable Mode of Action of The Drug in Trial Group-(12, 13)}

Action of ropana may be due to Vrana prasadan karma of ghrita and are effective to its maximum content by way of letting the wound becomes heal.

Karpoorghrita has vrana ropan potential and therefore shows this effect.

Vrana vedana may be reduced due to "eugenol" as it is analgesic, depresses the sensory nerves and is vedana sthapana.

Karpoor contains antiseptic compound - "cineol and terpineol", so is moderately antiseptic helped in prevent doshpak of the Vrana.

Vrana i.e granulation of wound may be attributed to the property of Karpoor that it stimulates local vessels thus increasing vascular supply required for healing.

Cineol is a rubefacient hence increses dermal uptake of the drug.

Karpoor belongs to the gana of sugandhi dravyas and possesses a pleasant odour since it contains "volatile oils" hence gandha may be absent at end of treatment.

Shatadhauta ghrita has Vrana ropana property hence disinfection and akruti can be explained.(14)

Hence, Trial group was seen to have significant results as the Control group. It means we can conclude that Vrana Karma with Karpoorghrita has significant results on Sadhyo Vrana as compared to PovidoneIodine.

\section{Conclusion}

1. In this clinical study it is seen that, Clinical parameters like Vedana, Varna, Akruti, Gandha were significantly reduced after treatment with Karpoorghrita in Trial group than treatment with betadine (povidone iodine) in Control Group; whereas srava was seen to be equal with treatment of Kaproopghrita as well as betadine.

2. Number of Days required for Ropana were less in Trial group than that in Control Group.

3. Hence the final conclusion that can be drawn is vranakarma in Sadhyo Vrana with Karpoorghrita is better than with povidone-Iodine.

\section{References}

1. Anant Damodar Athavale, Ashtanga Sangraha, $2^{\text {nd }}$ edition, pune, Shrimad Atreya Prakashan, 1980.page no. 126

2. Kavi.Dr.Ambikadatta Shastri, Sushruta Samhita, 
print 2014, varanasi, Choukhamba Bharati Academy, 2014.chikitsastan page no.1.

3. Bailey and love's, short practice of surgery, $25^{\text {th }}$ edition, great Britain, Edward Arnold publisher, 2008, page no.24.

4. Kavi.Dr.Ambikadatta Shastri, Sushruta Samhita, print 2014, varanasi, Choukhamba Bharati Academy, 2014.chikitsastan 2/85 page no.26.

5. Kaviraj shri govinddassen; Bhaishajya ratnavali, edited by prof.sidhhinandan Mishra reprinted 2009, Varanasi, Chaumhambha SurBharati prakashan, Varanasi, page no.830.

6. Kaviraj shri govinddassen; Bhaishajya ratnavali, edited by prof.sidhhinandan Mishra reprinted 2009, Varanasi, Chaumhambha SurBharati prakashan, Varanasi, page no.831.

7. Shabda kosh, vaidyak shabda sindu kosh, print 1999, Mumbai, Government press maharashtra, page no. 45 .

8. Supriya deshpande, Avinash deshpande, Suresh tupkari, Anoop Agnihotri, shata-dhauta ghrita-A case study, Indian journal of traditional knowledge, vol8(3), july2009, page no.387-391.
9. Awadhbhihari agnihotri, bhaishjya kalpana vidnyan, print 1887, varanasi, Chaumhambha SurBharati prakashan, 1987, page no.112.

10. Gogate VM, dravyaguna vidnyan, edition $1^{\text {st }}$, pune, vaidyamitra prakashan, $11 \mathrm{feb} .2008$.page no 307 , 706.

11. Mansukh.B.Patel, Yogesh.P.upadhhyay, Ward procedure, $6^{\text {th }}$ edition, new delhi, Elsevier publisher, 2009, page no20.

12. Eugenol-Jadhav BK, Khandelwal KR, Ketkar AR, Pisal SS.; Khandelwal; Ketkar; Pisal (February 2004). "Formulation and evaluation of mucoadhesive tablets containing eugenol for the treatment of periodontal diseases". Drug Dev Ind Pharm. 30 (2): 195-203.

13. Green, B. G. (1990). "Sensory characteristics of camphor". The Journal of investigative dermatology 94 (5): 662.

14. Supriya deshpande, Avinash deshpande, Suresh tupkari, Anoop Agnihotri, shata-dhauta ghrita-A case study, Indian journal of traditional knowledge, vol8(3), july2009, page no.387- 391. 